\title{
THE EFFECT OF STUDY ABROAD ON THE PRAGMATIC DEVELOPMENT OF THE INTERNAL MODIFICATION OF REFUSALS
}

\author{
Wei Ren
}

\begin{abstract}
Few studies have investigated the internal modification of refusals. This study investigates the effect of participating in a study abroad programme on the pragmatic development of Chinese students' employment of internal modifiers in their L2 English refusals. 20 Chinese students studying abroad and 20 Chinese students remaining at home participated in the study, and their L2 refusals were examined over the course of one academic year. Data were collected three times by an 8-situation Multimedia Elicitation Task. The results reveal that the two groups showed similar development with regard to the range of internal modification types in their refusals. Furthermore, with respect to the frequency of internal modifications, the results suggest that the differences between the two groups were not significant. However, analyses of the participants' use of individual internal modifications revealed different developmental patterns in the utilisation of 'address term' and 'downtoner'. These patterns indicate a unique effect of studying abroad on learners' pragmatic development, at least with respect to the aforementioned pragmatic aspects.
\end{abstract}

Keywords: Internal modification; Refusals; Study abroad; At home.

\section{Introduction}

The field of interlanguage pragmatics (ILP) has been criticised due to the tendency of many studies to focus on L2 use rather than L2 learning (Bardovi-Harlig 1999; Barron \& Warga 2007; Kasper \& Rose 2002; Kasper \& Schmidt 1996). The majority of research to date has adopted a comparative focus, highlighting some differences between learners and native speakers in the choice of speech acts, semantic formulas and content, as well as conventions of form, in the performance of a range of speech acts (Bardovi-Harlig 2001). However, a small but growing number of research studies (Barron 2003; Félix-Brasdefer 2007; Ren 2012; Rose 2000; Schauer 2009; Woodfield 2012) have sought to investigate the developmental aspect of ILP, responding to the call for further investigations into the development of learners' pragmatic competence (Bardovi-Harlig 1999; Kasper \& Rose 2002; Kasper \& Schmidt 1996). The present study aims to add to the body of this developmental research by exploring the development of learners' pragmatic competence to employ internal modification in their L2 English refusals. 
Internal modifications are elements within a speech act (head act), the presence of which is not essential for identifying the illocutionary force of the head act but serves to mitigate or emphasise its potential effects (Blum-Kulka et al. 1989). One example of such modifications is 'I'm afraid I can't go'. These modifications represent one factor determining the pragmatic effect of the speech act (cf. Faerch \& Kasper 1989), in addition to the learners' choice of speech act strategy and the employment of external modification. Therefore, close examinations of learners' employment of internal modification may help to provide a more complete picture of learners' pragmatic competence. However, to date, studies on internal modification have almost exclusively investigated the speech act of request (e.g., Blum-Kulka \& Levenston 1987; Economidou-Kogetsidis 2008, 2009; Faerch \& Kasper 1989; Hassall 2001; Woodfield 2008; and an edited volume by Economidou-Kogetsidis \& Woodfield 2012). There is a need to examine the internal modification of other speech acts (Woodfield \& Economidou-Kogetsidis 2012) to better understand patterns of internal modifications employed by L2 learners.

A refusal is generally considered to be a speech act whereby a speaker "denies to engage in an action proposed by the interlocutor" (Chen et al. 1995: 121). A refusal may be characterised as a response to another act (requests, invitations, suggestions and offers) rather than as an act initiated by the speaker. Although the speech act of refusing is one of the most widely researched speech acts in the field, the majority of studies on refusals have focused on refusal strategies and/or adjuncts to refusals (e.g., Beebe et al. 1990; Liao \& Bresnahan 1996; Nelson et al. 2002; Ren 2012; to name a few). Few studies, to our knowledge, have investigated the internal modifications of refusals, with the exception of four studies (Barron 2003; Bella 2011; Félix-Brasdefer 2004, 2008).

The present study aims to contribute to the existing ILP literature by investigating pragmatic development in learners' internal modification of refusals. Specifically, the study takes a longitudinal design to investigate Chinese graduate learners of English in two contexts: A study abroad context (henceforth SA) and an at-home context (hereafter $\mathrm{AH})$ at three different points over an academic year. The following sections will review recent studies in ILP developmental research that investigate refusals and the internal modification of speech acts before moving on to the methodology and findings of the present study.

\section{Literature review}

\subsection{Research on the pragmatic development of learners' interlanguage refusals}

This section reviews empirical studies on learners' pragmatic development in producing interlanguage refusals, focusing first on longitudinal studies and then on cross-sectional studies. Synchronic or single-moment (Kasper \& Rose 2002; Rose 2000) comparison studies are not reviewed because they focus on learners' pragmatic use rather than on learners' pragmatic development.

To date, only Bardovi-Harlig and Hartford (1993, 1996) and Barron (2003) have studied refusals longitudinally. In one of the earliest longitudinal studies on refusals, Bardovi-Harlig and Hartford $(1993,1996)$ investigated the pragmatic development of suggestions and refusals to suggestions in 10 advanced adult English learners in advising sessions. The findings indicated that the learners developed their pragmatic 
competence with regard to the choice of speech act and content, although they presented fewer changes in their ability to employ appropriate forms. The learners showed changes in their ability to employ appropriate speech acts by initiating more suggestions and fewer refusals. When the learners employed refusals, they refused more directly and explicitly, an approach that was considered to be more appropriate in advising sessions.

Barron's (2003) study was designed to investigate the pragmatic development of 33 Irish learners of German in their German requests, offers and refusals to offers using a free Discourse Completion Task (DCT). The findings indicated that overall, the sojourn in the L2 speech community resulted in some important developments in the learners' L2 pragmatic competence. However, it was also found that not all change necessarily represented developments towards the L2 norm, reflecting a non-linear path in the learners' L2 pragmatic development. The frequency of syntactic downgrading in the learner data changed over time (increased in some situations and decreased in others for both requests and offers), although these changes were comparatively minor and situation-dependent. The complexity of the syntactic downgraders employed in requests and offers increased over time in the L2 community. As for lexical/phrasal downgraders, the learners' employment of such modifiers was lowest in refusals relative to other speech acts, but this employment increased more than in the other speech acts (although the levels used in requests remained higher).

This review now turns to cross-sectional studies. Using DCTs, Takahashi and Beebe (1987) examined Japanese English learners' L2 refusals. Learners varied in both learning contexts (EFL vs. ESL) and L2 proficiency levels (lower vs. higher). With respect to L2 pragmatic development, no significant effect of proficiency was found in the EFL context, whereas in the ESL context, the frequency of direct refusals decreased as the proficiency increased. In addition, the higher proficiency ESL group appeared to have a wider range of expressions and more flexibility to adjust their level of directness according to different situations compared to the lower proficiency ESL group. The positive effect of study abroad was also evidenced in pragmatic transfer: Although pragmatic transfer existed in both the EFL and ESL contexts, L1 influence was more prevalent in the EFL context than in the ESL context.

Using role plays, Félix-Brasdefer (2004) investigated whether the ability of 24 advanced American Spanish learners to negotiate and mitigate refusals was influenced by the length of residence (LOR) in the target community. Learners varied in their LOR in the target communities. The findings indicate that learners with more extended LOR made more frequent attempts to negotiate and mitigate their refusals and approximated native Spanish speaker norms. Learners with a longer LOR produced a higher frequency and a greater variety of mitigators than learners with a shorter LOR.

To summarise, the above studies indicate a positive effect of study abroad on the pragmatic development of learners' refusals. Learners developed their pragmatic competence in employing more appropriate refusals (Bardovi-Harlig \& Hartford 1993, 1996; Barron 2003; Félix-Brasdefer 2004) and more internal modifiers (Barron 2003; Félix-Brasdefer 2004). 


\subsection{Research on learners' pragmatic development with a focus on internal modification}

This section reviews empirical studies investigating developmental patterns in learners' employment of internal modifications, focusing first on longitudinal studies and then on cross-sectional studies. Similar to in the above section, studies that are largely comparative in nature, contrasting request modifications by native speakers and L2 learners (e.g., Economidou-Kogetsidis 2008, 2009, 2012; Hassall 2001, 2012; Woodfield 2008), are not reviewed here.

Ellis (1992) reported a longitudinal study investigating the pragmatic development of two teenagers who were at an almost completely beginner level of English as L2 in a classroom context over 16 and 21 months using field notes and audio-recorded classroom conversations. The two learners' employment of internal modification did not appear to increase over time. There were few instances of internal modification in their requests even at the end of the study, most of which consisted of the use of 'please'.

Similar to Ellis (1992), Achiba (2003) examined the acquisition of requests in a child learner of L2 English, Yao, over a 17-month sojourn in Australia in a social context using audio and video recordings supplemented with diary keeping. Over the 17 months, Yao's employment of internal lexical/phrasal modifiers doubled. Achiba observed the high frequency of the internal modifier 'toner' (adverbial modifiers, e.g., 'maybe', 'just') relative to other lexical/phrasal modifiers in the second half of the study and a developing range of toners throughout the study.

Although the above two case studies were both based on naturally occurring data, several different methods have been employed to elicit experimental data. Using the Multimedia Elicitation Task (MET), Schauer (2009) examined the pragmatic development of nine German university students' L2 English requests during their oneyear study abroad programme. All of the SA learners increased their repertoire of internal modification devices during the sojourn to some extent. However, several internal modifiers (e.g., consultation devices, imposition minimisers, and tag questions) remained underdeveloped, and the degree of progress was negligible.

Woodfield (2012) investigated the pragmatic development of eight graduate students in their L2 English requests modification over an eight-month period in a British university. Data were collected at three points during the learners' sojourn by role plays. Overall, a linear decrease was found in the frequency of internal modification in the learners' requests across the 3 phases, representing a divergence from native speaker norms. Nevertheless, none of the eight learners employed the full range of internal modification devices in phase 1, although all learners acquired one or more internal modifiers in subsequent phases.

The above four studies all investigated learners' requests. Barron's (2003) study is the only longitudinal study that explored learners' internal modifications of refusals. Because it has been reviewed in Section 2.1, this study will not be repeated here (for the same reason, Félix-Brasdefer (2004) is not reviewed in the coming reviews of crosssectional studies; refer to Section 2.1 for details of the two studies).

The review now turns to studies employing a cross-sectional design. In one of the earliest cross-sectional examinations, Scarcella (1979) investigated requests made by adult Arabic learners of English at beginning and advanced levels using three role play situations. The results showed that some politeness features, such as the politeness marker (e.g., 'please'), appeared to emerge quite early in adult L2 acquisition, whereas 
others, such as 'the inclusive we' or more informal language (e.g., ellipsis, hedge), were indicative of a later stage in the acquisition process.

The effect of L2 proficiency on learners' requests was also observed in Otcu and Zeyrek's (2008) study, which compared two groups of Turkish English learners (lowand high-proficiency). The learners' employment of lexical/phrasal downgraders showed a clear developmental pattern. The high-proficiency group employed syntactic downgraders slightly more frequently compared to the low-proficiency group. On the contrary, the employment of cajolers displayed a different pattern. The high-proficiency students utilised cajolers more frequently than the low-proficiency students, who utilised cajolers less often than native English speakers, representing a divergence from native speakers with higher proficiency.

Using role plays, Göy et al. (2012) investigated internal modifications in requests of Turkish learners of English at two proficiency levels (beginner and upper intermediate). The major findings included that beginner learners underused syntactic and lexical/phrasal downgraders (except the politeness marker 'please') and that higher proficiency learners showed slow development in their employment of both subtypes of internal modification.

Using DCTs, Bella (2012) explored the external/internal modifications in requests by learners of Greek across three proficiency levels (lower intermediate, intermediate and advanced). Concerning internal modifications, the results suggested that the lower intermediate participants displayed significantly lower frequencies of syntactic modifiers than the more advanced groups. With respect to lexical/phrasal modifiers, both the intermediate and advanced learner groups employed significantly more lexical modifiers than the lower intermediate groups. In addition, the politeness marker 'please' was overused by the lower intermediate and intermediate groups but by not the advanced learners.

Rather than investigating adult L2 learners, Rose (2009) reported a cross-sectional study on Chinese learners' L2 English requests among three groups of secondary school students in Hong Kong using an oral DCT. The frequency of 'alerter' increased with higher proficiency, whereas the occurrence of the politeness marker 'please' decreased slightly with proficiency levels. Reliance on the modals 'can' and 'may' decreased with proficiency level, with a wider range of modals used at each level. However, other than the increased occurrence of 'please' in requests to higher-status interlocutors, there was not much evidence of sociopragmatic development.

Learners' pragmatic development of internal modification was also examined in the speech act of apology. Trosborg (1987) investigated apologies made by Danish English speakers across three proficiency levels (intermediate, lower advanced and higher advanced) using role plays. An increase was found in the employment of internal lexical modifiers relative to increasing L2 proficiency. Later, Trosborg (1995) conducted a broader study into three speech acts: Requests, complaints and apologies. Similarly, concerning the use of internal modification, some improvement was observed relative to increasing proficiency. For example, an increase of downgraders was observed across intermediate and lower advanced learners. However, nonlinear development was also observed, with intermediate learners internally modifying more frequently than the more advanced groups overall.

Using DCTs, Sabaté i Dalmau and Curell i Gotor (2007) compared apologies by Catalan learners of English at three proficiency levels (intermediate, advanced and proficient). The acquisition of apology intensification was observed to occur very 
gradually and at a very late stage. Even the proficient group did not employ all of the intensifiers available in English. Instead, this group relied heavily on a few lexical forms to mark pragmatic intent unambiguously, indicating that these learners' pragmalinguistic competence were not complete.

In summary, although the studies investigated internal modifications in different speech acts, the review has shown some common findings. First, with the exception of Ellis (1992), a positive effect of study abroad was observed in learners' repertoire of internal modifiers. Second, with the increase of proficiency levels, learners increased their employment of internal modifiers. Third, some modifiers may be acquired later than others. However, most studies have focused on requests. The limited number of studies on the internal modification of other speech acts reveals an important area of research yet to be investigated. Furthermore, none of the longitudinal studies investigated the $\mathrm{AH}$ contrast group more than once. Without comparison with an $\mathrm{AH}$ control group, "it is impossible to say with any certainty whether the effects were due to the stay in the target community" (Kasper \& Rose 2002: 225).

\subsection{Issues about native-speaker norms in interlanguage pragmatics}

As reviewed above, the majority of ILP studies (e.g., Barron 2003; Schauer 2009; Woodfield 2012) compare learners' data with those of native speakers, which are considered to be the baseline, to assess whether the learners are able to reach the L2 native norm. This 'native norm model' in L2 pragmatics has been criticised by many scholars (e.g., Dewaele 2007; Mori 2009; Yates 2010) and challenged by empirical findings (e.g., Barron 2003; Ren 2012; Xu 2009). First, the problem relates to the concept of 'native' (Davies 2004; Roever 2011; Yates 2010), as native speakers differ along the lines of socio-economic status, ethnicity, age, gender, education and so on. Second, L2 learners' deviations from the native speaker norm are not necessarily examples of pragmatic failure (Dewaele 2007; Siegal 1996). Some pragmatic deviations may be viewed as "charming and cute" in a particular situation (Iino 2006: 158). Third, there is little empirical support for the assumption that learners seek to achieve 'nativelike competence', which has been assumed in the L2 pragmatics literature (LoCastro 2001). Learners may present degrees of resistance to conforming to the native speakers' usages and intentionally diverge from the 'L2 pragmatic norms' (Barron 2003; Ishihara \& Tarone 2009; LoCastro 2001; Siegal 1996). Finally, native speakers may interpret L2 learners' performance differently from that of a native speaker (Hassall 2004). Maximal convergence to native speakers may not be judged appropriately by the native interlocutors (Cook 2001; Dewaele 2008).

The present study adopts the multi-competence view in second language acquisition (Cook 2002), treating the Chinese students as L2 users, which was defined after Cook $(1992,2002)$ as any person who uses a second language for a real-life purpose. The study thus aims to depict how Chinese SA students develop their competence to internally modify their L2 English refusals throughout the year rather than comparing their usage with that of a group of native speakers. The SA students' responses will then be compared with their AH counterparts to examine whether the developments, if any, benefit from studying abroad. 


\section{The study}

\subsection{Research questions}

The present study aims to add to the body of developmental research in L2 pragmatics and takes as its focus the pragmatic development of internal modification in L2 refusals of Chinese learners of English over an academic year. To be specific, the purpose of the present study is to investigate the effect of study abroad on the patterns of learners' employment of internal modification of refusals to address the following research questions:

1: To what extent does study abroad influence the range of internal modification types in Chinese learners' L2 English refusals?

2: To what extent does study abroad influence the frequency of internal modifications in Chinese learners' L2 English refusals?

3: To what extent does study abroad influence Chinese learners' employment of individual internal modifications in their L2 English refusals?

\subsection{Participants}

A total of 40 Chinese postgraduate students participated in this study: 20 Chinese master's students studying at a university in the UK (SA students) and 20 Chinese master's students studying at a university in China ( $\mathrm{AH}$ students). None of the participants had lived in an English-speaking country before taking part in this study, and none of the participants had specific instruction in pragmatics or speech acts before or during the study. The age of the SA students ranged from 22 to 31, with an average age of 24.95; the age of the AH students ranged from 22 to 26, with an average age of 24.05. The average length of prior formal study of English was 12.20 years for the SA students, ranging from 10 to 17 years, whereas that of the AH students was 11.95 years, ranging from 10 to 14 years. All of the SA students had taken the IELTS (International English Language Testing System), and their results ranged from 5.5 to 7 (mean $=6.35$, $\mathrm{SD}=0.52$ ), whereas all of the AH students had taken TEM-8 (Test for English Majors, Band 8), the most difficult national English test in Mainland China, and their results ranged from 60 to 72 (mean $=65.55, \mathrm{SD}=4.21$ ). That is to say, in the present study, the English proficiency of both the SA students and the AH students were rather advanced.

The SA students were recruited from different majors, including Engineering, Law, Management, and Education. Of these students, 7 were male and 13 were female. The AH students all majored in English Language and Literature. All of the AH students were female, which was partially due to the popularity of English majors among female students in Mainland China. The reason why only English Language and Literature majors were selected to join the AH student sample was to match the two groups with regard to their previous English level and their English input through instruction during the present study. Both the SA students and the AH students volunteered for the study. Although no financial compensation was given to the participants, there was a $100 \%$ completion rate. 


\subsection{Data collection methods and construction of the instrument}

It is generally agreed that there is no ideal method for all investigations in ILP. Instead, "methods need to be chosen so that they optimally answer the research questions" (Kasper 2008: 280). Because it would be impossible to gather enough natural data from comparable refusal situations and at different levels of social status to trace learners' pragmatic development (Cohen 2004; Kasper 2008), it was necessary to apply elicitation tasks. In the present study, data were collected with the Multimedia Elicitation Task (MET) (Ren 2011, 2012; Schauer 2004, 2009), which was a computerbased multimedia discourse completion task (DCT) in which participants were asked to sit at a computer, watch a series of slides, listen to instructions and to specifically recorded initiating utterances and respond orally.

The MET shares the advantages of the DCT, including the possibility of collecting a large amount of comparable data, the ease of administration, and the guarantee of standardisation, which addresses one of the disadvantages of role plays and a crucial issue for longitudinal L2 pragmatics study (Schauer 2009). Because role plays are usually conducted in dyads, it is important for the researcher to ensure that the data have been collected "under comparable circumstances without the interference of factors such as changes in the second person's mood or tone of voice" (Schauer 2009: 79). It is impractical for the present study to recruit the same interlocutors to elicit role plays with both SA learners and AH learners for an entire academic year. The MET is therefore designed to provide equal conditions for every participant, attempting to control for factors such as the interlocutor's mood or tone of voice by standardising the audiovisual input through a computerised presentation format. Such standardisation is critical in a study of this type, where learners' production must be compared with itself over time. In addition, the MET is able to provide participants more context clues (e.g., the image of the interlocutor) than the DCT, which increases the degree of naturalness (Félix-Brasdefer 2010).

Although it is possible that the MET does not produce data that are representative of actual language use in real interactions, the MET meets the need of the present study because it provides information regarding participants' pragmatic competence with respect to the use of the internal modifications of refusals and, as such, can be employed as a measure of changes in knowledge that might be indicative of development. Indeed, the focus of the study is not the participants' on-line pragmatic use in actual face-to-face interactions but their off-line pragmatic competence - what they know about the pragmatics of English (Rose 2009), for which the MET is a valid and reliable instrument, regardless of whether the data they yield are representative of face-to-face interactions.

In this study, the MET includes eight experiment scenarios focusing on refusals. The eight situations were designed to cover the four types of refusals, i.e., refusals to requests, to invitations, to suggestions, and to offers. Two situations were provided for each type of refusal. For each type of refusal, the description of each situation was based on the social status of the interlocutor in relation to the speaker: A professorstudent situation $(+\mathrm{P})$ and a student-student situation $(-\mathrm{P})$. The following provides a summary of the MET items:

S1: Your tutor asks you to give a presentation when you are busy. [Presentation: request, $+\mathrm{P}$ ] S2: Your classmate asks to borrow your notes, but you also need them. [Notes: request, -P] 
S3: Your tutor invites you to a farewell party; however, you are unable to attend. [Farewell: invitation, $+\mathrm{P}]$

S4: Your classmate asks you to have a dinner at a restaurant, but your budget is tight. [Restaurant: invitation, -P]

S5: Your tutor suggests that you choose an optional course, whereas you prefer to take another course. [Course: suggestion, $+\mathrm{P}$ ]

S6: Your classmate suggests that you skip class to go to a movie. [Movie: suggestion, -P]

S7: Your tutor offers you a piece of cake in a social event, but you don't like the flavour. [Social event: offer, $+\mathrm{P}]$

S8: Your classmate offers you a piece of cake at lunch but you are already full. [Lunch: offer, -P]

Each MET scenario contains two slides: An introductory slide (Figure 1) that briefly describes the actual situation and an actual conversation slide (Figure 2) that provides the participants with audiovisual information in the form of a photographic image depicting the situation of the conversation, an audio conversation and a written subtitle of the conversation.

\section{Scenario 1}

You meet your course tutor, Dr Mary White, after class in the corridor of your department. She asks you to give a presentation in next Wednesday's seminar. You have many other things to do at the moment, and you do not have enough time to prepare for the presentation.

Figure 1. Introductory slide for Scenario 1

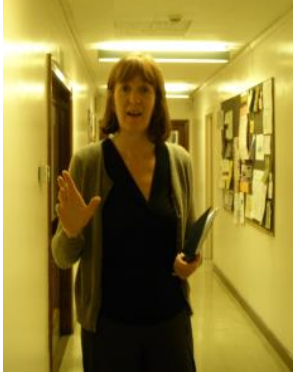

Audio input of the conversation

$\mathrm{Hi}$, we need more presenters for our seminar next Wednesday. I hope that you can give a presentation.

Figure 2. Actual scenario slide for Scenario 1

The introductory slide is included to offer participants background information on the context in which the conversation will occur (e.g., the relationship between the interlocutor and the participant, the general context of the conversation). This slide only sets the context in which participants are expected to refuse, whereas it does not force the participants to refuse. In other words, participants have the right to opt out (Bonikowska 1988). In the actual slide, the photograph provides the participants with vivid visual information of the interlocutor that can help them depict the interlocutor; the audio-recorded conversation makes the communication more natural, and the 
written subtitle for the conversation helps the participants understand the utterances in case they were unable to follow the initial utterance.

The scenarios were randomly ordered in each administration to reduce the potential of a memory effect by employing the same material three times at approximately four-month intervals with the same participants. There was no time pressure during the MET.

\subsection{The research procedure}

All data were collected in classrooms on the campuses of the two universities that the two groups of participants studied in. All participants who agreed to participate in the study signed a consent form before data collection. The MET was audio-recorded with the participants' permission. The METs were later transcribed for analysis.

Data collection took place at three different points in the 2009/2010 academic year for approximately ten months. For the SA students, the first phase of data collection occurred within the first month of their arrival in the UK, from August to the end of September 2009. The second phase was in January 2010, and the third occurred from the end of May to the beginning of June 2010. The data collection for the AH group followed a similar procedure as that of the SA group: The first phase was in October 2009, the second in March 2010, and the third in June 2010.

\subsection{Coding}

The internal modification of refusals has rarely been investigated, with the exception of four studies (Barron 2003; Bella 2011; Félix-Brasdefer 2004, 2008). Barron (2003) is among the first to investigate the internal modifications of refusals. In the study, Barron coded eight internal modifiers when analysing refusals to offers (Barron 2003: 360 361): (1) 'politeness marker' (e.g., 'please'); (2) 'understater' (e.g., 'a bit'); (3) 'hedge' (e.g., 'somehow', 'kind of'); (4) 'subjectiviser' (e.g., 'I'm afraid', 'I wonder/think /believe/suppose'); (5) 'downtoner' (e.g., 'perhaps', 'just', 'simply'); (6) 'cajoler' (e.g., 'actually', 'you know'); (7) 'appealer' (e.g., 'okay?', 'will you?'); and (8) combinations.

In the two studies of Félix-Brasdefer $(2004,2008)$, which investigated refusals to requests, to invitations and to suggestions, internal modifications were classified as follows: (1) 'mental state predicates' (e.g., 'I think', 'I believe'); (2) 'modal verbs' (e.g., 'probably', 'unfortunately'); (3) 'degree modifiers' (e.g., 'kind of', 'sort of'); and (4) 'tag questions in turn-final position' (e.g., 'is that okay?') (Félix-Brasdefer (2004) also classi- fied conditional forms).

Bella (2011) investigated the mitigation devices employed by native and nonnative speakers of Greek when refusing an invitation. She adopted a modified version of Barron (2003), including six categories: (1) 'understater'; (2) 'subjectiviser'; (3) 'downtoner'; (4) 'cajoler; (5) 'appealer'; and (6) 'solidarity marker' (e.g., diminutives, first name + possessive pronoun).

No published research to date has investigated the same group of speakers' (L1 or L2) pragmatic competence in their employment of internal modifications across the four types of refusals (i.e., refusals to requests, to invitations, to suggestions, and to offers).

The present study adopts a slightly modified version of Bella's (2011) taxonomy 
rather than Barron's (2003) and Félix-Brasdefer's (2004, 2008) for two reasons: (i) unlike Félix-Brasdefer's $(2004,2008)$ coding, Bella's taxonomy follows the tradition of the Cross-Cultural Speech Act Research Project (CCSARP) (Blum-Kulka et al. 1989), facilitating comparisons with other ILP studies; and (ii) unlike Barron's (2003) coding, which is based on written production data, Bella's (2011) coding is based on oral production data, so it would work better for the data set in the present study.

Two modifications are made to accommodate data elicited in the present study: (i) the 'solidarity marker' in Bella (2011) is replaced by the 'address term' because no other types of Bella's 'solidarity marker' appeared in the present study (e.g., diminutives); and (ii) in addition to the internal downgraders (i.e., modifiers that decrease the illocutionary force of a refusal) investigated by Bella (2011), upgraders (i.e., modifiers that increase the illocutionary force of a refusal) may also accompany refusal strategies (Barron 2007). Therefore, following the tradition of CCSARP, upgraders are also included in the present study.

Figure 3 illustrates the types of internal modification of refusals in the present study with examples from the data set.

Internal modification of refusals:

Downgraders:

a) Address term: e.g., professor; Sara

b) Understater: e.g., a bit; quite

c) Subjectiviser: e.g., I think; I am afraid

d) Downtoner: e.g., maybe; perhaps; just

e) Cajoler: e.g., you know; you see; actually

f) Appealer: e.g., OK?; What do you think?

Upgraders:

Intensifier: e.g., really; very

Figure 3. Categorisations of internal modification of refusals and examples from data

\subsection{Inter-rater reliability}

To establish inter-rater reliability, coding of the data was performed by the researcher and verified by a trained research assistant. The researcher coded all of the MET, i.e., 20 METs from each group (SA vs. AH) in each phase. The researcher then randomly selected $15 \%$ of the MET from each group from each phase for the research assistant to code. That is to say, the second rater coded 3 METs from each group in each phase.

The inter-rater reliability is $93.88 \%$ with Cohen's kappa $=.90$. Mackey and Gass (2005: 244-245) suggest that percentages over 90\% are ideal and that values of Cohen's kappa over .80 are excellent. The inter-rater reliability of coding in the present study may thus be considered excellent. For the cases where discrepancies were noted, the researcher discussed each case with the research assistant. Difficulties were resolved through discussion. Therefore, it was decided to include the data about which there was initial disagreement in the analysis as well. 


\section{Results}

\subsection{Range of internal modification types}

Table 1 shows the range of internal modification types for the SA group and the AH group across the three phases of data collection. The average range of internal modification types employed by the SA students was $3.45(\mathrm{SD}=1.10)$ in Phase $1,4.40$ $(\mathrm{SD}=1.05)$ in Phase 2 and $4.60(\mathrm{SD}=1.14)$ in Phase 3 . In contrast, the average range of internal modification types employed by the AH students was 3.25 (SD = 1.37) in Phase 1, $4.35(\mathrm{SD}=1.04)$ in Phase 2 and $4.80(\mathrm{SD}=1.01)$ in Phase 3. It appeared that the two groups showed a similar profile with respect to the development of the range of internal modification types in refusals.

Table 1. Summary of descriptive statistics on the range of internal modification types for the SA group and the $\mathrm{AH}$ group

\begin{tabular}{llllll}
\hline & & Mean & SD & Min & Max \\
\hline \multirow{3}{*}{ SA } & Phase 1 & 3.45 & 1.10 & 0 & 5 \\
& Phase 2 & 4.40 & 1.05 & 3 & 7 \\
& Phase 3 & 4.60 & 1.14 & 3 & 7 \\
\hline \multirow{3}{*}{ AH } & Phase 1 & 3.25 & 1.37 & 1 & 5 \\
& Phase 2 & 4.35 & 1.04 & 2 & 6 \\
& Phase 3 & 4.80 & 1.01 & 3 & 6 \\
\hline
\end{tabular}

A repeated-measures ANOVA was employed to study the effect of the learning environment (SA vs. $\mathrm{AH}$ ) on the range of internal modification types within the three phases of data collection. The statistical analyses indicated no main effect of learning environment $(\mathrm{F}(1,38)=0.03, \mathrm{p}=.96)$ but a main effect of time $(\mathrm{F}(1.41,53.52)=$ $52.40, \mathrm{p}<.001)$ on the participant's range of internal modification types. There was no significant interaction effect between the learning environment and time on the participants' range of internal modification types $(\mathrm{F}(1.41,53.52)=1.08, \mathrm{p}=.33)$. Therefore, it may be concluded that both the SA students and the AH students developed significantly across the three phases of data collection and that the two groups (SA vs. AH) were similar with respect to the range of internal modification types in their L2 English refusals.

To detect the location of differences, post hoc tests using the Bonferroni correction were employed separately on both groups' data. The results revealed that in both groups' data, significant difference existed in the increase from Phase 1 to Phase 2 ( $p$ $<.001$ and $\mathrm{p}<.01$ for the SA students and the AH students, respectively), the increase from Phase 1 to Phase 3 ( $\mathrm{p}<.001$ for both groups), and the increase from Phase 2 to Phase 3 ( $p<.05$ for the SA students and $\mathrm{p}<.01$ for the AH students). Thus, it can be concluded that regarding the range of internal modification types, both the SA students and the AH students developed significantly from Phase 1 to Phase 2, from Phase 2 to Phase 3, and from Phase 1 to Phase 3. 


\subsection{Frequency of internal modifiers}

Table 2 and Table 3 display the overall frequency of each internal modifier employed by the SA students and the AH students, respectively. As indicated in Table 2, the SA students overall employed 168 internal modifiers in Phase 1. The total frequency of internal modifiers decreased to 150 in Phase 2 but increased to 169 in Phase 3 in the SA students' data. In contrast, Table 3 reveals that the frequency of internal modifiers employed by the AH students increased steadily across the three phases ( $f=139,149$, 174 , respectively).

A repeated-measures ANOVA was employed to study the effect of the learning environment (SA vs. AH) on the frequency of the internal modification of refusals employed by the participants within the three phases of data collection. The statistical analyses indicated neither a main effect of learning environment $(F(1,38)=0.21, p$ $=.65)$ nor a main effect of time $(\mathrm{F}(2,76)=2.09, \mathrm{p}=.13)$. There was no significant interaction effect between the learning environment and time on the frequency of the internal modification of refusals employed by the participants $(F(2,76)=1.09, p=.34)$. The results indicated that with respect to the overall frequency of the internal modification of refusals, the difference between the SA students and the AH students was not statistically significant. Neither of the two groups (SA vs. AH) employed significantly more internal modifications in their L2 English refusals across the three phases of data collection.

Table 2. Frequency and percentage of internal modifications of the SA group

\begin{tabular}{|c|c|c|c|c|c|c|}
\hline \multirow{2}{*}{ Internal modifiers } & \multicolumn{2}{|c|}{ SA1 } & \multicolumn{2}{|c|}{ SA2 } & \multicolumn{2}{|c|}{ SA3 } \\
\hline & $f$ & $\%$ & $F$ & $\%$ & $f$ & $\%$ \\
\hline Downgraders & 120 & 71.43 & 109 & 72.00 & 127 & 75.15 \\
\hline Address term & 1 & 0.60 & 1 & 0.67 & 0 & 0 \\
\hline Understater & 7 & 4.17 & 9 & 6.00 & 7 & 4.14 \\
\hline Subjectiviser & 51 & 30.36 & 30 & 20.00 & 43 & 25.44 \\
\hline Downtoner & 40 & 23.81 & 37 & 24.67 & 48 & 28.40 \\
\hline Cajoler & 17 & 10.12 & 26 & 17.33 & 23 & 13.61 \\
\hline Appealer & 4 & 2.38 & 5 & 3.33 & 6 & 3.55 \\
\hline Upgraders & 48 & 28.57 & 42 & 28.00 & 42 & 24.85 \\
\hline Intensifiers & 48 & 28.57 & 42 & 28.00 & 42 & 24.85 \\
\hline Total & 168 & 100 & 150 & 100 & 169 & 100 \\
\hline
\end{tabular}

Notes: SA1: SA students phase 1; SA2: SA students phase 2; SA3: SA students phase 3. 
Table 3. Frequency and percentage of internal modifications of the AH group

\begin{tabular}{cllllll}
\hline \multirow{2}{*}{ Internal modifiers } & \multicolumn{2}{c}{$\mathrm{AH} 1$} & \multicolumn{3}{c}{$\mathrm{AH} 2$} & \multicolumn{3}{c}{$\mathrm{AH} 3$} \\
\cline { 2 - 7 } Downgraders & $f$ & $\%$ & $F$ & $\%$ & $f$ & $\%$ \\
Address term & 93 & 66.91 & 103 & 69.13 & 115 & 64.46 \\
Understater & 2 & 2.16 & 0 & 0 & 8 & 4.60 \\
Subjectiviser & 39 & 1.44 & 10 & 6.71 & 5 & 2.87 \\
Downtoner & 20 & 14.39 & 25 & 16.78 & 27 & 15.52 \\
Cajoler & 19 & 13.67 & 19 & 12.75 & 25 & 14.37 \\
Appealer & 10 & 7.19 & 8 & 5.37 & 7 & 4.02 \\
Upgraders & 46 & 33.09 & 46 & 30.87 & 59 & 33.91 \\
Intensifiers & 46 & 33.09 & 46 & 30.87 & 59 & 33.91 \\
\hline Total & 139 & 100 & 149 & 100 & 174 & 100 \\
\hline Notes: AH1:AHS & 10 & 41 & 27.52 & 43 & 24.71 \\
\hline
\end{tabular}

Notes: AH1: AH students phase 1; AH2: AH students phase 2; AH3: AH students phase 3;

\subsection{Employment of individual internal modifications}

This section analyses the participants' employment of individual internal modifications across the eight situations. Due to space limitations, only 'downtoner' and 'address term' are reported because i) 'downtoner' is the only internal modification that reveals significant differences between the two groups and, ii) although not significantly different, the employment of 'address term' in the two groups reveals insightful differences.

\subsubsection{Downtoner}

As shown in Table 2 in Section 4.2, the number of 'downtoner' employed by the SA students decreased slightly from Phase $1(f=40)$ to Phase 2 ( $f=37$ ) but increased sharply in Phase 3 ( $\mathrm{f}=48$ ). In contrast, the AH students increased their employment of 'downtoner' across the three phases ( $\mathrm{f}=20,25,27$, respectively, see Table 3 in Section 4.2).

A repeated-measures ANOVA was employed to study the effect of learning environment (SA vs. AH) on the frequency of 'downtoner' employed by the participants within the three phases of data collection. The statistical analyses indicated no main effect of time $(\mathrm{F}(1.70,64.40)=1.44, \mathrm{p}=.24)$ but a main effect of learning environment $(\mathrm{F}(1,38)=5.11, \mathrm{p}=.03)$ on the participant's employment of 'downtoner'. There was no significant interaction effect between the learning environment and time ( $F(1.70$, $64.40)=0.53, p=.56)$. Therefore, it may be concluded that the learning environment (SA vs. AH) had a significant effect on the frequency of 'downtoner' employed by the participants.

To detect the location of the differences, post hoc tests using the Bonferroni correction were employed in both groups' data separately. The results did not reveal any 
significant difference. However, between-group comparisons revealed that a significant difference existed in Phase 1 between the frequency of 'downtoner' employed by the SA group and the AH group $(\mathrm{t}=2.15, \mathrm{p}=.04)$, and a nearly significant difference existed in Phase $3(\mathrm{t}=2.00, \mathrm{p}=.05)$, indicating that the SA students employed more downtoners than their $\mathrm{AH}$ counterparts.

\subsubsection{Address term}

Table 4 presents the frequency of the use of 'address term' by the SA and AH students across the eight situations.

Table 4. Frequency of 'address term' employed across individual situations

\begin{tabular}{|c|c|c|c|c|c|c|c|c|c|}
\hline \multirow{2}{*}{ Address terms } & \multicolumn{2}{|c|}{ Request } & \multicolumn{2}{|c|}{ Invitation } & \multicolumn{2}{|c|}{ Suggestion } & \multicolumn{2}{|c|}{ Offer } & \multirow{2}{*}{ Total } \\
\hline & $+\mathrm{P}$ & $-\mathrm{P}$ & $+\mathrm{P}$ & $-\mathrm{P}$ & $+\mathrm{P}$ & $-\mathrm{P}$ & $+\mathrm{P}$ & $-\mathrm{P}$ & \\
\hline SA1 & - & - & 1 & - & - & - & - & - & 1 \\
\hline SA2 & 1 & - & - & - & - & - & - & - & 1 \\
\hline SA3 & - & - & - & - & - & - & - & - & - \\
\hline AH1 & 1 & - & - & 1 & - & - & 1 & - & 3 \\
\hline AH2 & - & - & - & - & - & - & - & - & - \\
\hline $\mathrm{AH} 3$ & 4 & - & 2 & - & 1 & - & 1 & - & 8 \\
\hline
\end{tabular}

As shown in Table 4, 'address term' was not frequently employed by the SA students or the AH students. Among the SA students, only one of the 20 SA students (5\%) employed 'address term' in Phase 1, which was utilised once in response to an invitation from a high-status interlocutor. In Phase 2, another student (5\%) employed 'address term' once in response to a request from a high-status interlocutor, whereas no SA student utilised any address term in Phase 3. Among the $20 \mathrm{AH}$ students, 'address term' was employed three times by 2 students $(10 \%)$ in Phase 1 . No AH student employed 'address term' in Phase 2, while four (20\%) employed 'address term', aggregately eight times, in Phase 3.

The following are examples of address terms employed in the present study.

\section{SA students}

'Oh, congratulations, Sara, oh, but I am afraid I can't go. But, yeah... have a good time.' (SA1, Phase 1)

'Oh, Sara, I am very sorry about that, because I didn't prepare it very well...' (SA10, Phase 2)

\section{AH students}

'Sorry, professor. You know, I have a lot of work to do. So, I don't have enough time to do this presentation ...' (AH15, Phase 1)

'Yes, that is true that we haven't been together for a long time. But Maria, you know, I have been busy recently. And besides, Browns are too expensive for me to go there.' (AH16, Phase 1)

'Thank you very much, $\underline{D r}$....En, because I have little time, so, I can recommend someone ...en, to you. He can do, he can do it also well.' (AH5, Phase 3) 
'Thank you for your invitation, Miss Miss Sara, but you know, I am very interested in the Language and Culture. ...' (AH12, Phase 3)

The examples reveal that the SA students rarely employed 'address term' in their refusals. When they did employ an address term, they knew they could address the high-status interlocutors by their first names according to the L2 culture. In the present study, only one type of 'address term' was employed by the SA students to address a high-status interlocutor in Phase 1 and Phase 2, which was the interlocutor's first name. No SA students employed an address term in refusing an equal-status interlocutor.

In contrast, among the $\mathrm{AH}$ students, address terms were employed three times in Phase 1. In addition to the first name employed in response to an invitation from an equal-status interlocutor, the title 'professor' was employed twice in response to a highstatus interlocutor: Once in reply to a request and the other time to an offer. No AH student employed address terms in Phase 2, whereas they employed address terms eight times in Phase 3, in which 'title' (e.g., Dr., Professor) was employed by three AH students $(15 \%)$ to address a high-status interlocutor. The higher frequency of 'title' employed indicated that the AH students felt it necessary to address the high-status interlocutor by their title rather than by their first name. In addition, another AH student mistakenly employed 'gender + first name' (e.g., Miss Sara) rather than 'gender + last name', indicating that this AH student wanted to show respect to the lecturer but did not have the appropriate pragmalinguistic competence to achieve it.

\section{Summary and discussion}

\subsection{Noticing, study abroad and pragmatic development of the internal modification of refusals}

The study was designed to investigate the effect of study abroad on the pragmatic development of Chinese students' employment of the internal modification of refusals. The first research question examined the extent to which study abroad affected the Chinese students' range of internal modification types in their L2 English refusals. Both the SA students and the AH students employed new types of internal modifications in their refusals across the three phases of data collection. In both groups' data, significant differences existed in the increases from Phase 1 to Phase 2, from Phase 2 to Phase 3, and from Phase 1 to Phase 3. The findings demonstrate that the SA students' range of internal modification types developed significantly during the present study, and the effect was even significant between Phase 1 and Phase 2. This finding indicates that the SA students' L2 English pragmatic competence developed significantly after a year's study in the UK in terms of the range of internal modification types in their L2 refusals. Even after 4 months of study in the L2 community, the students had already acquired significantly more types of internal modifications in their L2 refusals. These findings are in tandem with previous findings from longitudinal request studies, such as Schauer (2009) and Woodfield (2012), in which the SA students were found to acquire new types of internal modifications in their L2 requests during their study abroad.

The second research question examined the extent to which study abroad affected the frequency of internal modifications in the Chinese students' L2 English refusals. The results indicate that no significant differences were found among any comparisons 
across the three phases of data collection in either the SA group's or the AH group's data. That is, with respect to the overall frequency of internal modifications of refusals, differences between the two groups were not statistically significant.

The third research question explored the two groups' employment of the individual internal modification of refusals across 8 situations. A statistical difference was only observed with respect to the employment of 'downtoner' in the two groups' refusals. In addition, although both groups employed 'address term' infrequently, the two groups' employment of 'address term' revealed qualitative differences. The SA students rarely employed 'address term' in their refusals. When they did employ an address term, they knew they could address the high-status interlocutors by their first names according to the L2 culture. In contrast, the AH students employed 'title' to address the high-status interlocutors much more frequently, particularly in the last phase of data collection. This finding implies that the AH students might feel it necessary to address the high-status interlocutor by their titles rather than by their first names, reflecting that the $\mathrm{AH}$ students might lack the relevant L2 sociopragmatic knowledge that the SA students developed during their study abroad sojourn. However, it must be acknowledged that given the low frequency of 'address terms' employed in the present study, the analyses and interpretations should be treated with caution and can only be considered tentative.

It is possible that the development concerning the employment of the aforementioned internal modifications may be easier to achieve in a study abroad context than in an at-home context, reflecting an advantage of a study abroad context over an at-home context reported in previous studies (e.g., Bardovi-Harlig \& Dörnyei 1998; Schauer 2009). In the noticing hypothesis (Schmidt 1990, 1993, 1995, 2001), attention to the pragmalinguistic or sociopragmatic information to be acquired is the necessary condition for pragmatic learning to occur. For input to become intake, and thus available for further processing, relevant input features must be 'noticed'. For the learning of L2 pragmatics, learners must notice the relevant "linguistic forms, functional meanings, and the relevant contextual features" (Schmidt 1993: 35). Therefore, the acquisition of certain pragmatic elements, particularly elements such as internal modifiers that "do not carry information crucial to the task" (Schmidt 1990: 149), was challenging even for advanced learners.

AH students may lack sufficient range and amount of input that SA students may have access to. Therefore, the lack of a sufficient range and the emphasis of relevant input may lead to AH students not being able to notice certain internal modifications in English refusals (Bardovi-Harlig \& Hartford 1993, 1996). Furthermore, it is also likely that even if AH learners have an amount of L2 input available similar to that of SA learners, the intensity of contact in the L2 may be different in SA contexts and in AH contexts. As Bardovi-Harlig and Dörnyei (1998) commented, the development of SA learners' pragmatic competence "may have come from the friction of their daily interaction: The pressure not only making themselves understood but also of establishing and maintaining smooth relationships with native speakers" in the L2 community (Bardovi-Harlig \& Dörnyei 1998: 253). Moreover, the saliency of certain modifications in the L2 input may be different for learners in SA contexts and in AH contexts. Learners in SA contexts are more likely to encounter a critical incident (Barron 2003), "a situation where there is a communication problem between people of different cultures" (Tomalin \& Stempleski 1993: 84). The critical incidents may force SA learners to notice some pragmatic elements in the L2 input. Consequently, learners' 
L2 pragmatic acquisition may be facilitated by noticing particular internal modification and understanding what has been noticed (Schmidt 1993).

\subsection{Stages of pragmatic development}

Based on Achiba (2003) and Ellis (1992), the two longitudinal investigations on child learners' requests development in an ESL context, Kasper and Rose (2002: 140) proposed five stages of the pragmatic development of requests: 1) pre-basic (highly context-dependant, no syntax, no relational goals); 2) formulaic (unanalysed formulas and imperatives); 3) unpacking (formulas incorporated into productive language use); 4) pragmatic expansion (adding new forms to pragmalinguistic repertoire, increasing use of mitigation); and 5) fine-tuning the requestive force and context.

Félix-Brasdefer (2007) investigated the development of requests among adult American learners of Spanish (beginning, intermediate and advanced) in a foreign language (FL) context. Four stages of pragmatic development were identified: Pre-basic, formulaic, unpacking and pragmatic expansion. Félix-Brasdefer summarised that the first two stages were found in the data of the beginning learners and that the last two were representative of the intermediate and advanced learners. Bella's study (2012) on the requests of adult learners of Greek in a FL context also supported the developmental stages of pragmatic competence proposed by Kasper and Rose (2002). In this crosssectional study of learners across three different proficiency levels (lower intermediate, intermediate and advanced), the performance of lower intermediate learners exhibited phenomena generally attributed to the basic/formulaic stages, whereas the intermediate and advanced learners' performance displayed the main characteristics of the unpacking and pragmatic expansion stages (Bella 2012).

These studies on the developmental stages of pragmatic competence (Achiba 2003; Bella 2012; Ellis 1992; Félix-Brasdefer 2007) all focused on requests. Little research has been conducted to investigate learners' pragmatic developmental stages in other speech acts. In the present study, both the SA students and the AH students employed new types of internal modifications in their refusals across the three phases of data collection. This finding indicates that both the SA and AH groups expanded their pragmalinguistic repertoire during the present study, representing the characteristics of the pragmatic expansion stage. However, the two groups displayed differences in their employment of 'address term' and 'downtoner'. During the study abroad programme, the SA students might have been able to develop their pragmatic competence to finetune their employment of internal modifiers in refusals according to various contexts (e.g., social status, initiating speech acts), representing the characteristics of the finetuning stage (Kasper \& Rose 2002). In contrast, the fine-tuning of internal modification to contexts was not observed in the AH students' refusals.

The results thus indicate a unique advantage of acquiring pragmatic competence to fine-tune internal modifiers in refusals in a study abroad context, suggesting that the ability to fine-tune internal modifiers in refusals may remain problematic for learners in a foreign language context, even if they are at an advanced level. It is worth noting that the AH students in the present study were all master's students majoring in English. Their L2 English proficiency was quite advanced. Therefore, taken with the findings of Félix-Brasdefer (2007) and Bella (2012), it is possible that learners in a foreign language context may have difficulties in reaching the fine-tune stage of pragmatic 
development, at least without the intervention of instruction. This possibility highlights the need for pedagogical intervention in support of learners' pragmatic competence. Future studies are needed to further investigate this assumption.

\subsection{Implications for longitudinal pragmatic research}

The present study found that concerning the range of internal modification types in L2 refusals, both the SA students and the AH students significantly developed their pragmatic competence. Therefore, it cannot be concluded that the SA students' pragmatic development was due to the study abroad experience alone. The two groups of participants (SA vs. AH) developed in a similar pattern in this respect. No significant difference was found in each phase of the data collection between the two groups. This result indicates no advantage for the SA students with regard to the development of the range of internal modification types in L2 refusals, mirroring some previous findings in the literature (Ren 2012; Rodriguez 2001; Taguchi 2007, 2008; Xu 2009). For example, Ren (2012) investigated Chinese learners' range of refusal strategy types and of refusal adjunct types and found that both the SA group and the $\mathrm{AH}$ group displayed similar development.

Similar findings were also observed in studies examining learners' pragmatic perception of speech acts (Rodriguez 2001; Xu 2009) and learners' pragmatic comprehension of refusals and implications (Taguchi 2007, 2008). Although SA students and AH students may have different opportunities in terms of their exposure to L2 target input, the learning environment does not necessarily influence the amount of target input available. With the help of English films or other materials, AH students' L2 pragmatic competence, particularly their L2 pragmalinguistic competence, may also develop (Rose 2001), given exposure to pragmatic input for learning.

The findings imply that AH students' L2 pragmatic competence should also be examined across different points in longitudinal L2 pragmatics research (Ren 2012), which has been neglected in ILP studies; little research in ILP has investigated the AH contrast group longitudinally.

\section{Limitations and future research}

The present study investigates the effect of study abroad on the employment of internal modification in refusals among Chinese students of English at an advanced level. The results cannot be generalised to all Chinese learners of English. Rather than focusing on advanced learners, future research could include participants from a variety of L2 proficiency levels to provide a more comprehensive view of the effect of study abroad on the development of learners' L2 pragmatic competence concerning internal modification of refusals. Furthermore, the present study adopts the multi-competence view in second language acquisition (Cook 2002) and depicts how the Chinese students' L2 English refusal modifications develop throughout the year. However, the lack of native-speaker baseline data makes it difficult to reach definite conclusions concerning the learners' development. Future research might want to include a native speaker group. In addition, more studies are needed to explore the internal modification of other speech 
acts (e.g., apologies, compliments) to provide more insights into the nature of internal modifications and the patterns of their development.

Finally, the limitations of the present study involve the nature of the data gathered. Despite the advantages of the MET, the present study could not investigate learners' pragmatic competence in realising refusals through longer negotiations because the MET only elicited the production of one-turn utterances. This shortcoming may be addressed by employing role plays as elicitation instruments (e.g., Félix-Brasdefer 2004). However, as discussed in Section 3.3, the advantages of the MET, such as the guarantee of standardisation (Schauer 2009), address one of the disadvantages of role plays that is a crucial issue for a longitudinal L2 pragmatics study.

\section{Conclusion}

The study has examined the effect of study abroad on the pragmatic development of Chinese students' employment of internal modifications in their L2 English refusals. The results reveal that both the SA students and the AH students employed new types of internal modifications across the three phases of data collection and that the two groups showed similar development in the range of internal modification types. Furthermore, with respect to the frequency of internal modifications, the results suggest that differences between the SA students and the $\mathrm{AH}$ students were not statistically significant. These findings indicate that there was no significant benefit of study abroad in these two respects. However, analyses of the employment of individual internal modifier showed that the two groups displayed different developmental patterns in their employment of 'address term' and 'downtoner'. These findings indicate a unique contribution of study abroad on learners' pragmatic development, at least with respect to the aforementioned aspects. Experience studying abroad may increase the possibility that learners notice certain pragmatic elements, thus facilitating learners' L2 pragmatic acquisition.

The overall findings also suggest that both the SA students and the AH students demonstrated the characteristics of the pragmatic expansion stage but that only the SA students showed phenomena of the fine-tune stage (Kasper \& Rose 2002). It is possible that the fine-tune stage might be difficult to reach for learners in a foreign language context (cf. Bella 2012; Félix-Brasdefer 2007).

Very few studies (Barron 2003; Bella 2011; Félix-Brasdefer 2004, 2008) have investigated the internal modification of refusals. The present study contributes to the existing literature by analysing internal modifications of refusals longitudinally to enable a comparison of findings of studies on different speech acts. Analysing how speakers modify different speech acts internally to have a comprehensive view of their pragmatic competence would benefit the pragmatics literature. Furthermore, the study has shown the necessity of investigating both the experimental group and the contrast group with a similar design of data collection (Ren 2012) in longitudinal L2 pragmatics research on the effect of study abroad. In doing so, it is possible to say with certainty whether the effects were due to study abroad (cf. Kasper \& Rose 2002). 


\section{Acknowledgements}

This work is supported in part by the President Fund of UCAS (Y2510FY00). I would like to thank the anonymous reviewers for their extensive comments and suggestions during the peer-review process. Any remaining errors are my own.

\section{References}

Achiba, Machiko (2003) Learning to request in a second language : A study of child interlanguage pragmatics. Clevedon: Multilingual Matters.

Bardovi-Harlig, Kathleen (1999) Exploring the interlanguage of interlanguage pragmatics: A research agenda for acquisitional pragmatics. Language Learning 49.4: 677-713.

Bardovi-Harlig, Kathleen (2001) Evaluating the empirical evidence: Grounds for instruction in pragmatics? In Kenneth R. Rose, and Gabriele Kasper (eds.), Pragmatics in Language Teaching. Cambridge: Cambridge University Press, pp. 13-32.

Bardovi-Harlig, Kathleen, and Zoltan Dörnyei (1998) Do language learners recognize pragmatic violations? Pragmatic versus grammatical awareness in instructed L2 learning. TESOL Quarterly 32.2: $233-263$

Bardovi-Harlig, Kathleen, and Beverly Hartford (1993) Learning the rules of academic talk: A longitudinal study of pragmatic development. Studies in Second Language Acquisition 15: 279-304.

Bardovi-Harlig, Kathleen, and Beverley Hartford (1996) Input in an institutional setting. Studies in Second Language Acquisition 17: 171-188.

Barron, Anne (2003) Acquisition in interlanguage pragmatics: Learning how to do things with words in a study abroad context. Amsterdam: John Benjamins Publishing Company.

Barron, Anne (2007) "Ah no honestly we're okay:" Learning to upgrade in a study abroad context. Intercultural Pragmatics 4.2: 129-166.

Barron, Anne, and Muriel Warga (2007) Acquisitional pragmatics: Focus on foreign language learners. Intercultural Pragmatics 4.2: 113-127. 
Beebe, Leslie M., Tomoko Takahashi, and Robin Uliss-Weltz (1990) Pragmatic transfer in ESL refusals. In R. Scarcella, E. Anderson, and S. Krashen (eds.), Developing communicative competence in a second language. Rowley, MA: Newbury House, pp. 55-73.

Bella, Spyridoula (2011) Mitigation and politeness in Greek invitation refusals: Effects of length of residence in the target community and intensity of interaction on non-native speakers' performance. Journal of Pragmatics 43: 1718-1740.

Bella, Spyridoula (2012) Pragmatic development in a foreign language: A study of Greek FL requests. Journal of Pragmatics 44: 1917-1947.

Blum-Kulka, Shoshana, Juliane House, and Gabriele Kasper (eds.) (1989) Cross-cultural pragmatics : Requests and apologies. Norwood, NJ: Ablex.

Blum-Kulka, Shoshana, and W.A. Levenston (1987) Lexico-grammatical pragmatic indicators. Studies in Second Language Acquisition 9: 155-170.

Bonikowska, Malgorzata P. (1988) The choice of opting out. Applied Linguistics 9.2: 169-181.

Chen, Xing, Lei Ye, and Yanyin Zhang (1995) Refusing in Chinese. In Gabriele Kasper (ed.), Pragmatics of Chinese as native and target language. Honolulu, Hawaii: University of Hawaii at Manoa, pp. 121-161.

Cohen, Andrew D. (2004) Assessing speech acts in a second language. In B. Boxer, and A.D. Cohen (eds.), Studying speaking to inform second language learning. Clevedon, England: Multilingual Matters, pp. 302-327.

Cook, Vivian (1992) Evidence for multicompetence. Language Learning 42.4: 557-591.

Cook, Vivian (2001) Second language learning and language teaching (3rd ed. ed.). London: Arnold.

Cook, Vivian (2002) Backgroud to the 12 user. In Vivian Cook (ed.), Portraits of the L2 user. Clevedon: Multilingual matters, pp. 1-28.

Davies, Alan (2004) The native speaker in applied linguistics. In Alan Davies, and Catherine Elder (eds.), The handbook of applied linguistics. Oxford: Blackwell, pp. 431-450.

Dewaele, Jean-Marc (2007) Context and L2 users' pragmatic development. In Hua Zhu, Paul Seedhouse, Wei Li, and Vivian Cook (eds.), Language learning and teaching as social interaction. Basingstoke: Palgrave Macmillan, pp. 162-183. 
Dewaele, Jean-Marc (2008) "Appropriateness" in foreign language acquisition and use: Some theoretical, methodological and ethical considerations. IRAL 46: 235-255.

Economidou-Kogetsidis, Maria (2008) Internal and external mitigation in interlanguage request production: The case of Greek learners of English. Journal of Politeness Research 4.1: 111-138.

Economidou-Kogetsidis, Maria (2009) Interlanguage request modification: The use of lexical/phrasal downgraders and mitigating supportive moves. Multilingua 28.1: 79-112.

Economidou-Kogetsidis, Maria (2012) Modifying oral requests in a foreign language: The case of Greek Cypriot learners of English. In Maria Economidou-Kogetsidis, and Helen Woodfield (eds.), Interlanguage request modification. Amsterdam: John Benjamins Publishing Company, pp. 163-201.

Ellis, Rod (1992) Learning to communicate in the classroom: A study of two language learners' requests. Studies in Second Language Acquisition 14: 1-23.

Félix-Brasdefer, J. César (2004) Interlanguage refusals: Linguistic politeness and length of residence in the target community. Language Learning 54.4: 587-653.

Félix-Brasdefer, J. César (2007) Pragmatic development in the Spanish as a FL classroom: A crosssectional study of learner requests. Intercultural Pragmatics 4: 253-286.

Félix-Brasdefer, J. César (2008) Politeness in Mexico and the United States : A contrastive study of the realization and perception of refusals. Amsterdam: John Benjamins Publishing Company.

Félix-Brasdefer, J. César (2010) Data collection methods in speech act performance: Acts, role plays, and verbal reports. In Alicia Martinez Flor, and Esther Uso-Juan (eds.), Speech act performance: Theoretical, empirical and methodological issues. Amsterdam: John Benjamins Publishing Company, pp. 41-56.

Faerch, Claus, and Gabriele Kasper (1989) Internal and external modification in interlanguage request realization. In Shoshana Blum-Kulka, Juliane House, and Gabriele Kasper (eds.), Cross-cultural pragmatics: Requests and apologies. Norwood, NJ: Ablex, pp. 221-247.

Göy, Elif, Deniz Zeyrek, and Bahar Otcu (2012) Developmental patterns in internal modification of requests: A quantitative study on Turkish learners of english. In Maria Economidou-Kogetsidis, and Helen Woodfield (eds.), Interlanguage request modification. Amsterdam: John Benjamins Publishing Company, pp. 51-86.

Hassall, Tim (2001) Modifying requests in a second language. IRAL 39: 259-283. 
Hassall, Tim (2004) Through a glass, darkly: When learner pragmatics is misconstrued. Journal of Pragmatics 36: 997-1002.

Hassall, Tim (2012) Request modification by Australian learners of Indonesian. In Maria EconomidouKogetsidis, and Helen Woodfield (eds.), Interlanguage request modification. Amsterdam: John Benjamins Publishing Company, pp. 203-242.

Iino, Masakazu (2006) Norms of interaction in a Japanese homestay setting: Toward a two-way flow of linguistic and cultural resources. In Margaret A. DuFon, and Eton Churchill (eds.), Language learners in study abroad contexts. Clevedon: Multilingual Matters, pp. 151-173.

Ishihara, Noriko, and Elaine Tarone (2009) Subjectivity and pragmatic choice in L2 Japanese: Emulating and resisting pragmatic norms. In Naoko Taguchi (ed.), Pragmatic competence. Berlin: Mouton de Gruyter, pp. 101-128.

Kasper, Gabriele (2008) Data collection in pragmatics research. In Helen Spencer-Oatey (ed.), Culturally speaking: Culture, communication and politeness theory (2nd ed.). London: Continuum, pp. 279-303.

Kasper, Gabriele, and Kenneth R. Rose (2002) Pragmatic development in a second language. Oxford: Blackwell.

Kasper, Gabriele, and Richard Schmidt (1996) Developmental issues in interlanguage pragmatics. Studies in Second Language Acquisition 18: 149-169.

Liao, Chao-chih, and Mary Jiang Bresnahan (1996) A contrastive pragmatic study on American English and Mandarin refusal strategies. Language Sciences 18.3-4: 703-727.

LoCastro, Virginia (2001) Individual differences in second language acquisition: Attitudes, learner subjectivity, and L2 pragmatic norms. System 29: 69-89.

Mackey, Alison, and Susan Gass (2005) Second language research: Methodology and design. Mahwah, NJ: Lawrence Erlbaum.

Mori, Junko (2009) Commentary: The social turn in second language acquisition and Japanese pragmatics research: Reflection on ideologies, methodologies and instructional implications. In Naoko Taguchi (ed.), Pragmatic competence. Berlin: Mouton de Gruyter, pp. 335-358.

Nelson, Gayle L., Joan Carson, Mahmoud Al Batal, and Waguida El Bakary (2002) Cross-cultural pragmatics: Strategy use in Egyptian Arabic and American English refusals. Applied Linguistics 23.2: 163-189. 
Otcu, Bahar, and Deniz Zeyrek (2008) Development of requests: A study on Turkish learners of english. In M. Puetz, and J. Neff-Van Aertselaer (eds.), Developing contrastive pragmatics: Interlanguage and cross-cultural perspectives. Berlin/New York: Mouton de Gruyter, pp. 265-299.

Ren, Wei (2011) The effect of study abroad on L2 pragmatic development: A longitudinal investigation. Ph.D. Dissertation, University of Bristol.

Ren, Wei (2012) Pragmatic development in chinese speakers' L2 English refusals. In Leah Roberts, Christina Lindqvist, Camilla Bardel, and Niklas Abrahamsson (eds.), Eurosla yearbook (vol. 12). Amsterdam: John Benjamins Publishing Company, pp. 63-87.

Rodriguez, Silvia (2001) The perception of requests in spanish by instructed learners of Spanish in the second- and foreign-language contexts: A longitudinal study of acquisition patterns. Ph.D. Dissertation, Indiana University, Bloomington, IN.

Roever, Carsten (2011) Testing of second language pragmatics: Past and future. Language Testing 28.4: 463-481.

Rose, Kenneth R. (2000) An exploratory cross-sectional study of interlanguage pragmatic development. Studies in Second Language Acquisition 22: 27-67.

Rose, Kenneth R. (2001) Compliments and compliments responses in film: Implications for pragmatics research and language teaching. IRAL 39: 309-327.

Rose, Kenneth R. (2009) Interlanguage pragmatic development in Hong Kong, phase 2. Journal of Pragmatics 41.11: 2345-2364.

Sabaté i Dalmau, Maria, and Hortènsia Curell i Gotor (2007) From "sorry very much" to "I'm ever so sorry": Acquisitional patterns in L2 apologies by Catalan learners of English. Intercultural Pragmatics 4.2: 287-315.

Scarcella, Robin (1979) On speaking politely in a second language. In C. Yorio, K. Perkins, and J. Schachter (eds.), On tesol'79: The learner in focus. Washington, DC: TESOL, pp. 275-287.

Schauer, Gila A. (2004) May you speak louder maybe? Interlanguage pragmatic development in requests. In S.H. Foster-Cohen, M. Sharwood Smith, Antonella Sorace, and M. Ota (eds.), Eurosla yearbook (Vol. 4). Amsterdam: John Benjamins Publishing Company, pp. 253-273.

Schauer, Gila A. (2009) Interlanguage pragmatic development: The study abroad context. London: Continuum. 
Schmidt, Richard (1990) The role of consciousness in second language learning. Applied Linguistics 11.2: 129-158.

Schmidt, Richard (1993) Consciousness, learning, and interlanguage pragmatics. In Gabriele Kasper, and Shoshana Blum-Kulka (eds.), Interlanguage pragmatics. New York: Oxford University Press, pp. 21-42.

Schmidt, Richard (1995) Consciousness and foreign language learning: A tutorial on the role of attention and awareness in learning. In R. Schmidt (ed.), Attention and awareness in foreign language learning. Honolulu: University of Hawaii, Second Language Teaching and Curriculum Center, pp. 1-63.

Schmidt, Richard (2001) Attention. In Peter Robinson (ed.), Cognition and second language instruction. Cambridge: Cambridge University Press, pp. 3-32.

Siegal, Meryl (1996) The role of learner subjectivity in second language sociolinguistic competency: Western women learning Japanese. Applied Linguistics 17.3: 356-382.

Taguchi, Naoko (2007) Development of speed and accuracy in pragmatic comprehension in English as a foreign language. TESOL Quarterly 41.2: 313-338.

Taguchi, Naoko (2008) The role of learning environment in the development of pragmatic comprehension: A comparison of gains between EFL and ESL learners. Studies in Second Language Acquisition 30: 423452.

Takahashi, Tomoko, and Leslie M. Beebe (1987) The development of pragmatic competence by Japanese learners of English. JALT Journal 18: 131-155.

Tomalin, Barry, and Susan Stempleski (1993) Cultural awareness. Oxford: Oxford University Press.

Trosborg, Anna (1987) Apology strategies in native/non-natives. Journal of Pragmatics 11: 147-167.

Trosborg, Anna (1995) Interlanguage pragmatics: Requests, complaints, apologies. Berlin: Mouton de Gruyter.

Woodfield, Helen (2008) Interlanguage requests in English: A contrastive study. In Martin Putz, and J. Neff-Van Aertselaer (eds.), Developing contrastive pragmatics: Interlanguage and cross-cultural perspectives. Berlin/New York: Mouton de Gruyter, pp. 231-264.

Woodfield, Helen (2012) "I think maybe I want to lend the notes from you": Development of request modification in graduate learners. In Maria Economidou-Kogetsidis, and Helen Woodfield (eds.), Interlanguage request modification. Amsterdam: John Benjamins Publishing Company, pp. 9-49. 
Woodfield, Helen, and Maria Economidou-Kogetsidis (2012) Modification in interlanguage requests. In Maria Economidou-Kogetsidis, and Helen Woodfield (eds.), Interlanguage request modification. Amsterdam: John Benjamins Publishing Company, pp. 1-8.

$\mathrm{Xu}$, Wei (2009) Gaining pragmatic competence in English as a second and a foreign language: The effects of the learning environment and overall L2 proficiency. Ph.D. Dissertation, University of Nevada, Reno.

Yates, Lynda (2010) Pragmatic challenges for second language learners. In Anna Trosborg (ed.), Pragmatics across languages and cultures. Berlin: Mouton de Gruyter pp. 287-308.

WEI REN is currently a postdoc researcher at the National Key Research Centre for Linguistics \& Applied Linguistics at Guangdong University of Foreign Studies and a lecturer at the University of Chinese Academy of Sciences. His research interests include L2 Pragmatics and Cross-Cultural Pragmatics. His recent publications include papers in EUROSLA Yearbook 2012, Journal of Pragmatics, and Research Trends in Intercultural Pragmatics.

Address: Centre for Linguistics and Applied Linguistics, Guangdong University of Foreign Studies, Guangzhou 510420, China. E-mail: renweixz@yahoo.com 